\title{
Особливості діагностики пацієнтів із симптоматичними тунельованими коронарними артеріями
}

\author{
Гогаєва О. К. \\ ДУ «Національний інститут серцево-судинної хірургії імені М. М. Амосова НАМН України» (Київ)
}

\begin{abstract}
Стаття присвячена аномалії розташування вінцевих артерій - тунельованим коронарним артеріям (ТКА). На основі найбільшого у світі досвіду, який налічує 347 симптоматичних пацієнтів, автор провів фундаментальний аналіз і впровадив у практику ефективні методи верифікації цієї аномалії. Вперше були виявлені високоспецифічні ЕКГ-ознаки, що дозволило вдосконалити ангіографічні ознаки м’язових «місточків» (MM).
\end{abstract}

Ключові слова: тунельовані коронарні артерії, м’язові «місточки», інтрамуральний хід, діагностика.

Тунельована коронарна артерія (ТКА) - вроджена аномалія розташування вінцевої артерії під м'язовим сегментом. Вперше залягання епікардіальної вінцевої артерії в м'язовому сегменті описав Рейман у 1737 році, назвавши м'язовий сегмент місточком, а артерію, розташовану в його межах, тунельованою (пірнаючою). Частота виявлення цієї аномалії при патологоанатомічному дослідженні становить 7-85\% випадків, що значно відрізняється від ангіографічних знахідок, які варіюють від 0,5 до 4,5\% [1-10]. Ці факти свідчать про труднощі прижиттєвої діагностики ТКА, визначаючи актуальність вивчення і необхідність розробки алгоритмів діагностики та лікування хворих із цією аномалією. Клінічна картина, а іноді й безсимптомний перебіг утруднює прижиттєву діагностику цієї аномалії. Таким чином, можна сказати, що, незважаючи на велику кількість повідомлень, більшість із них базується на поодиноких випадках, а тому має інформаційний характер [5-7].

Труднощі діагностики диктують нагальну необхідність пошуку нових ознак. У літературі не представлені клінічні особливості пацієнтів із симптоматичними ММ, які відрізняють їх від інших форм ішемічної хвороби серця (IXC), немає чітких електрокардіографіч-

\section{Таблиця 1}

Клінічні прояви у пацієнтів із TKA

\begin{tabular}{ll} 
Клінічні ознаки & \multicolumn{1}{c}{$\mathbf{n}(\%)$} \\
\hline Стенокардія & $347(100 \%)$ \\
\hline Задишка & $233(67,1 \%)$ \\
\hline Аритмія & $212(60,09 \%)$ \\
\hline Артеріальна гіпертонія & $261(75,2 \%)$ \\
\hline Інфаркт міокарда в анамнезі & $188(54,1 \%)$ \\
\hline Психосоматичні розлади & $332(95,6 \%)$
\end{tabular}

них (ЕКГ) ознак ТКА, відсутнє порівняння ангіографічних даних з інтраопераційними знахідками.

Мета роботи - вивчення клініко-діагностичних ознак ТKА і розробка алгоритмів діагностики пацієнтів із симптоматичними ТКА.

Методи дослідження. Всім пацієнтам проводили ЕКГ, ЕхоКГ, холтерівський моніторинг ЕКГ, коронаровентрикулографію з провокаційними пробами, внутрішньокоронарне ультразвукове дослідження.

Результати та обговорення. Протягом 13 років в Інституті спостерігалося 347 пацієнтів із симптоматичними TКА (260 чоловіків, 87 жінок), діагностованими під час коронарографії. Середній вік хворих становив $48 \pm 28$ років (з 13 до 80 років). Ми помітили, що аномалія частіше проявляється у хворих на 3-4-й декаді життя. Клінічні особливості пацієнтів із ТКА представлені в табл. 1.

До основних причин госпіталізації пацієнтів належали стенокардія (табл. 2), що асоціювалася з фізичною активністю або емоційним стресом, інфаркт міокарда в анамнезі, гострий коронарний синдром. Звертає на себе увагу значна кількість психосоматичних порушень $(95,6 \%)$ у вигляді підвищеної тривожності, страху смерті, нападів задухи $(67,1 \%)$ та гіпертонічних кризів $(75,2 \%)$.

Важливо, що однією з клінічних особливостей цієї аномалії є непереносимість нітрогліцерину, що виникає через посилення систолічної компресії тунельова-

\section{Таблиця 2}

Розподіл пацієнтів із TKА за функціональним класом стенокардіі

\begin{tabular}{ccccc} 
& \multicolumn{4}{c}{ Функціональний клас стенокардії } \\
\cline { 2 - 5 } & І ФК & II ФК & III ФК & IV ФК \\
\hline n (\%) & $87(25,08 \%)$ & $98(28,24 \%)$ & $146(42,07 \%)$ & $16(4,61 \%)$
\end{tabular}



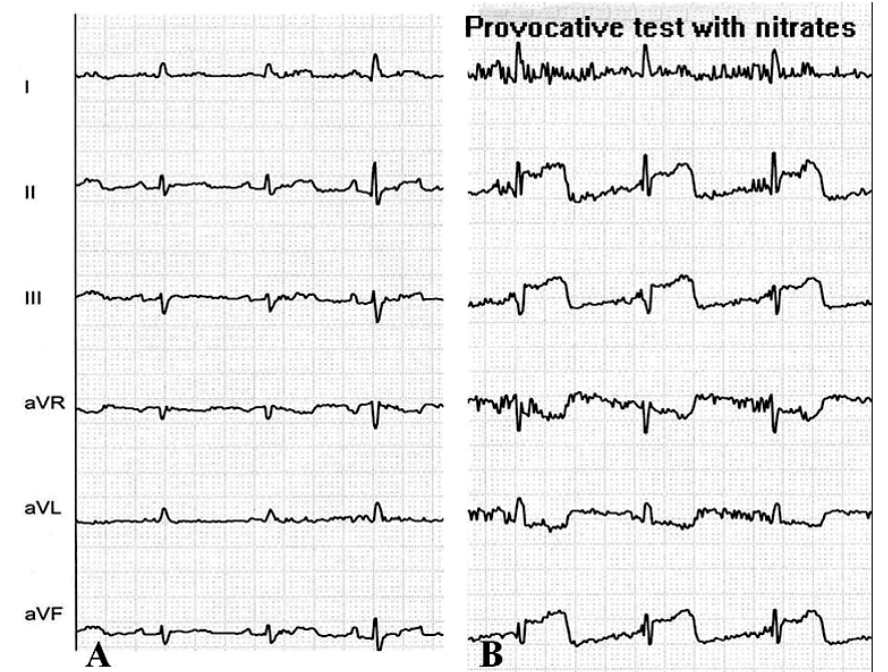

Рис. 1. Зміни ЕКГу пацієнта з ТКА у стані спокою (A) та після внутрішньовінцевої інфузії ізосорбіду динітрату (B)

ного сегмента вінцевої артерії. Спостерігається погіршення самопочуття і виникнення нападів стенокардії з ішемічними змінами на ЕКГ після прийому пацієнтами ізосорбіду динітрату (рис. 1).

Порівнюючи ЕКГ, ангіографічні дані та інтраопераційні знахідки, ми ідентифікували високоінформативні ЕКГ-ознаки у вигляді транзиторних змін глибини зубця Т у лівих грудних відведеннях, що виникають завдяки динамічному характеру компресії вінцевої артерії (патент України на винахід № 40899) (рис. 2). Виявлені ЕКГ-ознаки дозволяють нам із високою вірогідністю діагностувати наявність ТКА ще на догоспітальному етапі.

Ретельний аналіз ангіографічних даних і високоспецифічні ЕКГ-ознаки дали нам можливість значно покращити ангіографічну діагностику ТКА.

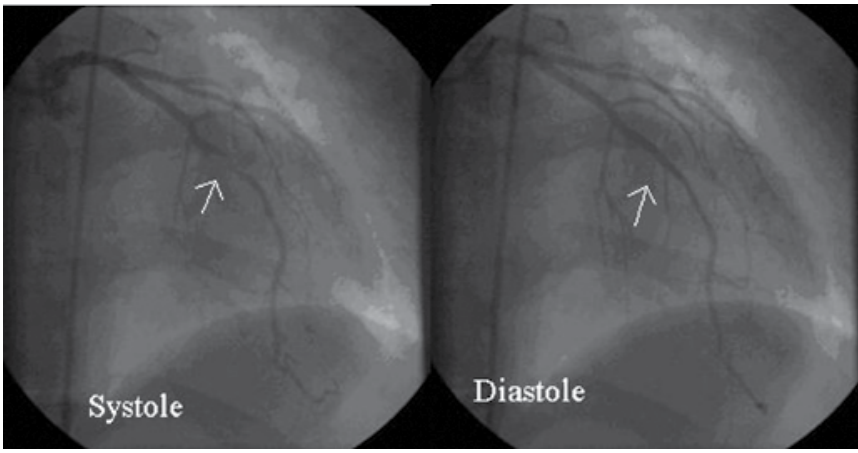

Рис. 3. Коронарографія пацієнтки К. (26 років) із 100\% систолічною компресією середньої третини передньої міжшлуночкової артерії лівої коронарної артерії (ПМШГЛКА)

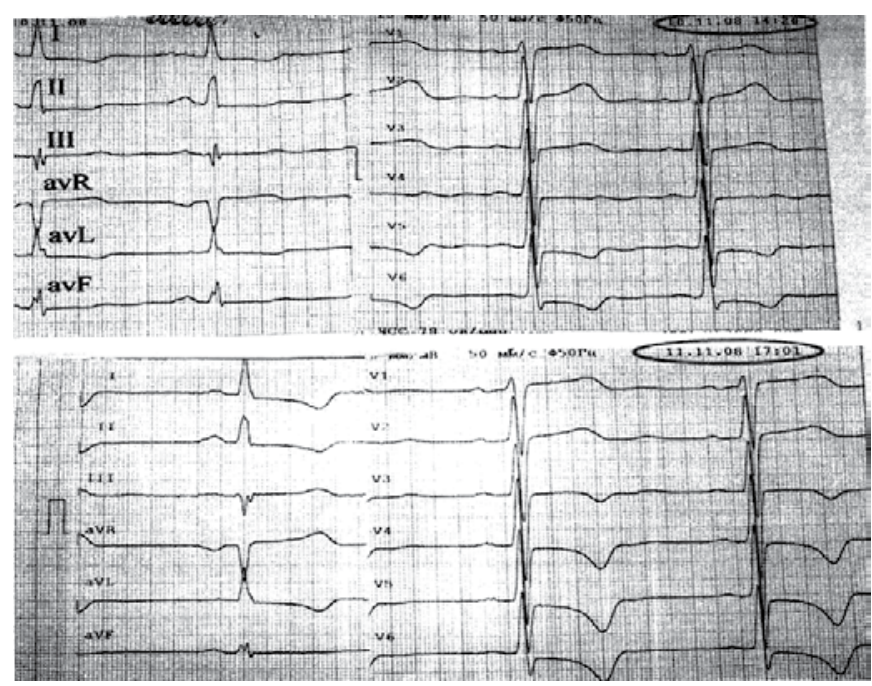

Рис. 2. Транзиторна ішемія як ЕКГ-ознака ТКА

Типовий ангіографічний симптом ТКА (так званий симптом «доїння») спостерігався у 92\% пацієнтів із найкращою візуалізацією в лівій передній косій проекції з каудальним нахилом (рис. 3).

У більшості випадків $(96,8 \%)$ внутрішньом'язове розташування мала передня міжшлуночкова гілка лівої коронарної артерії (ПМШГ ЛКА), але в деяких випадках спостерігалось інтраміокардіальне розташування декількох вінцевих артерій (табл. 3).

Середня систолічна компресія вінцевої артерії була $70 \%$, довжина тунельованого сегмента варіювала від 3 до 40 мм (у середньому 28 мм).

Крім описаних ангіографічних ознак, ми виявили непряму ознаку ТКА у вигляді гіпо-, акінезії передньої стінки та верхівки лівого шлуночка при відсутності значущої систолічної компресії у $94(27,08 \%)$ пацієнтів (патент України на винахід № 96548). Внутрішньоко-

\section{Таблиця 3}

Локалізація внутрішньоміокардіальних вінцевих артерій

\begin{tabular}{lc} 
TKA $^{*}$ & $\mathbf{n = 3 4 7}(\%)$ \\
\hline ПМШГЛКА & $336(96,8 \%)$ \\
\hline ПМШГ+ПКА & $1(0,3 \%)$ \\
\hline ПМШГ+ДГ+ОГ & $5(1,4 \%)$ \\
\hline ПКА & $3(0,9 \%)$ \\
\hline ДГ & $1(0,3 \%)$ \\
\hline Септальні гілки ПМШГ & $1(0,3 \%)$
\end{tabular}

*ПМШГ ЛКА - передня міжшлуночкова гілка лівої вінцевої артерії, ПКА - права вінцева артерія, ДГ - діагональна гілка, ОГ огинаюча гілка 


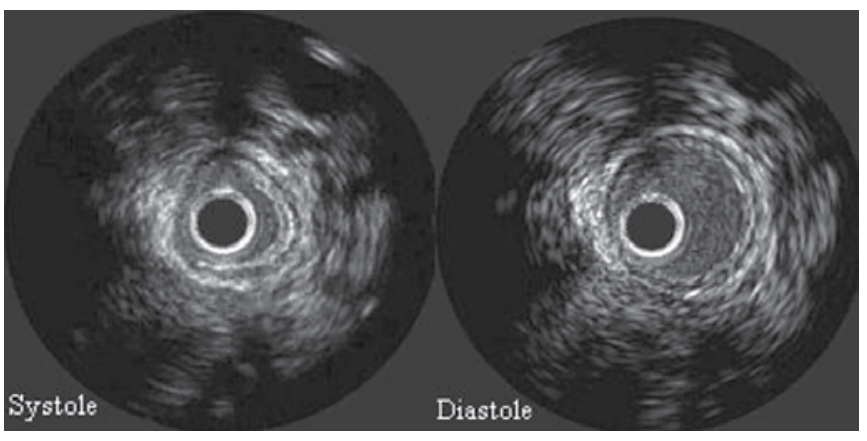

Рис. 4. ВКУЗД середньої третини ПМШГЛКА із симптомом «напівмісяия» в систолу та діастолу

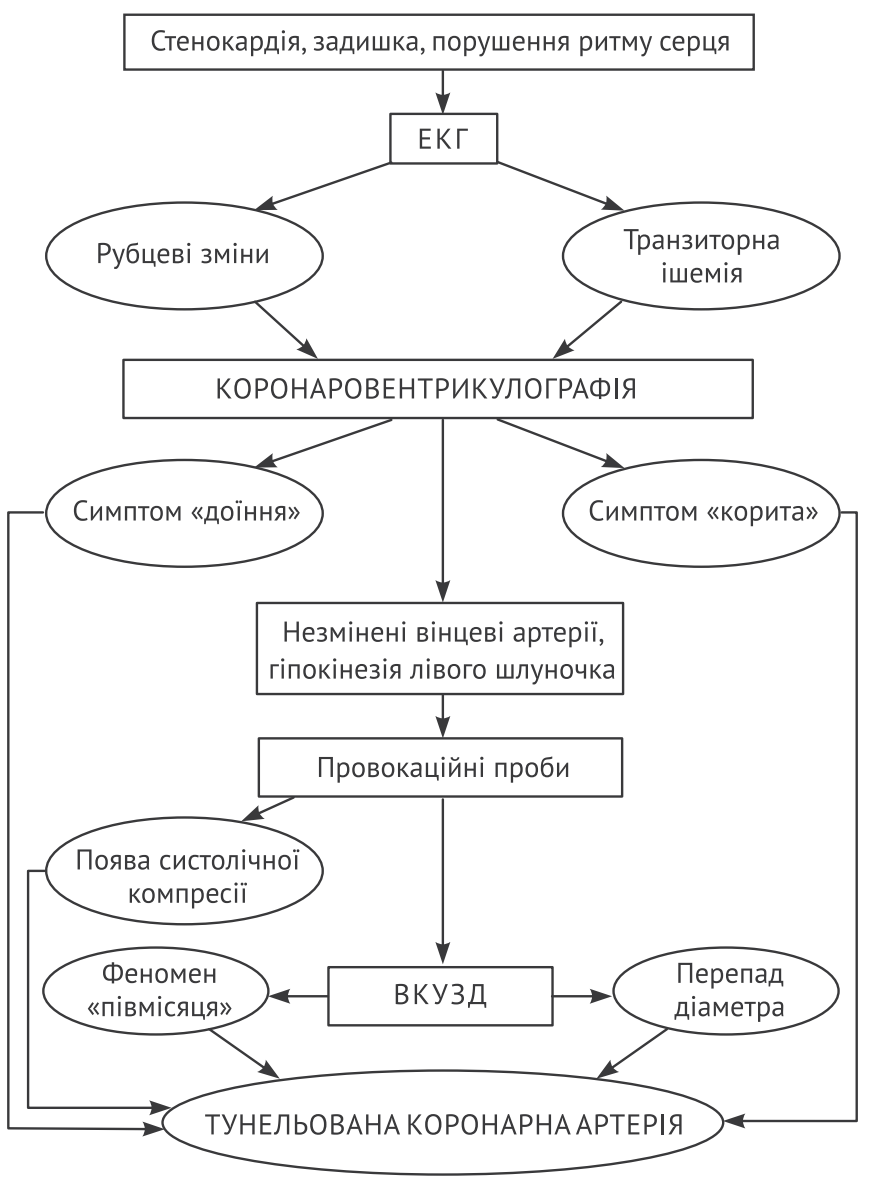

Рис. 5. Алгоритм діагностики симптоматичних TKA

ронарна провокаційна проба з ізосорбідом динітратом під час ангіографії покращила діагностику ТКА на 75,7\% (патент України на винахід № 87347).

В суперечливих випадках пацієнтам проводили внутрішньокоронарне ультразвукове дослідження (ВКУЗД), завдяки якому визначали зміни діаметра тунельованої артерії як у систолу, так і в діастолу, а також товщину стінки вінцевої артерії. Специфічний фено- мен «напівмісяця», як результат зовнішньої деформації вінцевої артерії, спостерігався у 82,9\% пацієнтів (рис. 4).

На основі багаторічного досвіду спостереження пацієнтів із ТКА було впроваджено алгоритм діагностики, наведений на рис. 5.

\section{Висновки}

1. ТКА частіше маніфестує у пацієнтів на 3-4-й декаді життя і супроводжується психосоматичними розладами $(95,6 \%)$.

2. Інтраміокардіальне розташування ПМШГ ЛКА на ЕКГ проявляється транзиторними змінами глибини інвертованого зубця Т у лівих грудних відведеннях та відсутністю росту зубця $\mathrm{r}$ в перегородковій ділянці.

3. Розроблені високоспецифічні ЕКГ-ознаки внутрішньоміокардіального розташування вінцевих артерій дозволяють ще на догоспітальному етапі діагностувати ТКА і своєчасно розпочати лікування.

4. Важка візуалізація ТКА під час коронарографії пов'язана з динамічною компресією вінцевої артерії.

5. Внутрішньокоронарні провокаційні тести з ізосорбідом динітратом покрашують діагностику ТКА $(75,7 \%)$.

6. Гіпо-, акінезія передньої стінки та верхівки лівого шлуночка при відсутності значимої систолічної компресії ПМШГ ЛКА може бути непрямою ознакою ТКА.

\section{Література}

1. Ferreira A. G., Trotter S., Konig B., et al. Myocardial bridges: morphological and functional aspects. Br. Heart J. 1991; Vol. 66: 364-367.

2. Juilliure Y., Berder V., Suty-Selton C., et al. Isolated myocardial bridges with angiographic milking of the left anterior descending coronary artery: a long-term follow-up study. Am. Heart J. 1995; Vol. 129: 663-665.

3. Noble J., Bourassa M., Petitclerc R., et al. Myocardial bridging and milking effect of the left anterior descending coronary artery: normal variant or obstruction? Am. J. Cardiol. 1976; Vol. 37: 993-999.

4. Angelini P., Trivellato M., Donis J., et al. Myocardial bridges: a review. Prog. Cardiovasc. Dis. 1983; Vol. 26: $75-88$

5. Grigoriu C., Astarastoae V., Grigoriu B. Myocardial bridging and sudden death. Rev. Med. Chir. Soc. Med. Nat. Iasi. 2001; Vol. 105 (1): 77-82.

6. Lee MS, Chen C-H. Myocardial Bridging: An Upto-Date Review. The Journal of invasive cardiology. 2015;27(11):521-528.

7. Knyshov G., Gogayeva E., Rudenko A., Dzakhoieva L., Lazorishinez V. Nyryayushhie arterii - norma ili patologiya? Mezhdunarodnyj medicinskij zhurnal. 2006 (1): $14-18$.

8. Gogayeva E. Tunnelirovannye koronarnye arterii: osobennosti klinicheskogo techeniya. Sercevo-sudinna hirurgiya: 
shhorich. nauk. prac Asociaciï sercevo sudinnih hirurgiv Ukraini. 2007; 15: 65-66.

9. Yuan SM. Myocardial bridging. Braz J Cardiovasc Surg. 2016 Feb;31(1):60-2.

10. Kiris, Tuncay et al. A Rare Case of Myocardial Bridge Involving Left Anterior Descending, Obtuse Marginal and
Ramus Intermediate Coronary Arteries. Kardiochirurgia i Torakochirurgia Polska Polish Journal of Cardio-Thoracic Surgery 2016; 13 (4): 368-369.

\title{
Features of diagnostics for patients with symptomatic tunneled coronary arteries
}

\section{Olena Gogayeva}

\author{
National M. M. Amosov Institute of Cardiovascular Surgery National Academy of Medical Sciences of Ukraine (Kyiv)
}

Given article is devoted to location anomaly of coronary arteries so called tunneled coronary arteries (TCA). Based on the world's biggest experience of 347 symptomatic patients, author performed fundamental analysis and practiced the most effective methods for verification of patients with such an anomaly. The main reason for the hospitalization of patients was angina pectoris, $54.1 \%$ of them had myocardial infarction in anamnesis, $95.6 \%$ of patients had psychosomatic disorders; dyspnea attacks had $67.1 \%$ of them. It is important to note that one of the clinical features of TCA is nitrates intolerance, due to an increase in systolic compression of tunneled segment of the coronary artery (CA). The new high peculiar features of ECG were detected for the first time and that allowed to improve an angiographic verification of TCA. Transient change in the depth of inverted T wave in left precordial leads on ECG is due to the dynamic nature of compression of the intramural CA. The typical angiographic symptom of TCA - «milking-effect» was observed in $92 \%$ of patients. In $96.8 \%$ of cases myocardial bridge was settled down at the LAD, with average systolic compression $70 \%$, average length of the tunneled segment was $28 \mathrm{~mm}$. Implementation in practice provocative test with isosorbide dinitrate during angiography has improved visualization of systolic compression of coronary artery (CA) in $75.7 \%$ cases. Also we found an indirect sign of myocardial bridge in the form of hypokinesis of the anterior wall and apex of the left ventricle in $94(27.08 \%)$ patients. The specific "half-moon" phenomenon on IVUS was met in $82.9 \%$ of cases.

Key words: tunnelled coronary arteries, intramural course of coronary arteries, myocardial «bridges», diagnostic. 